Narco Cinema 


\section{Latino Pop Culture}

Series Editor: Frederick Luis Aldama

Books in the series give serious critical attention to all facets of Latino popular culture. Books focus on topics that generally pertain to the making and consuming of Latino pop culture, including music, performance and body art, TV shows, film, comic books, web media, pop art, lowriders, sartorial wear, video games, sports, and cuisine, among many other areas.

Frederick Luis Aldama, The Ohio State University, USA.

Titles:

Latinos in the End Zone: Conversations on the Brown

Color Line in the NFL

by Frederick Luis Aldama and Christopher González

Reclaiming Poch@ Pop: Examining the Rhetoric of Cultural Deficiency by Cruz Medina

Narco Cinema: Sex, Drugs, and Banda Music in Mexico's B-Filmography by Ryan Rashotte 


\title{
Narco Cinema
}

\section{Sex, Drugs, and Banda Music in Mexico's B-Filmography}

\author{
Ryan Rashotte
}




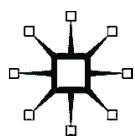

NARCO CINEMA

Copyright (C) Ryan Rashotte, 2015.

Chapter artwork by Ayumi Shimizu

Softcover reprint of the hardcover 1st edition 2015 978-1-137-50147-9

All rights reserved.

First published in 2015 by

PALGRAVE MACMILLAN ${ }^{\circledR}$

in the United States-a division of St. Martin's Press LLC,

175 Fifth Avenue, New York, NY 10010.

Where this book is distributed in the UK, Europe and the rest of the world, this is by Palgrave Macmillan, a division of Macmillan Publishers Limited, registered in England, company number 785998, of Houndmills, Basingstoke, Hampshire RG216XS.

Palgrave Macmillan is the global academic imprint of the above companies and has companies and representatives throughout the world.

Palgrave ${ }^{\circledR}$ and Macmillan ${ }^{\circledR}$ are registered trademarks in the United States, the United Kingdom, Europe and other countries.

ISBN 978-1-349-50551-7

ISBN 978-1-137-48924-1 (eBook)

DOI $10.1057 / 9781137489241$

Library of Congress Cataloging-in-Publication Data

Rashotte, Ryan, 1979-

Narco cinema : sex, drugs, and banda music in Mexico's

b-filmography / Ryan Rashotte.

pages $\mathrm{cm}$. - (Latino pop culture)

Summary: "This book provides the first comprehensive study of narco cinema, a cross-border exploitation cinema that, for over forty years, has been instrumental in shaping narco-culture in Mexico and the US borderlands. Identifying classics in its mammoth catalogue and analyzing select films at length, Rashotte outlines the genre's history and aesthetic criteria. He approaches its history as an alternative to mainstream representation of the drug war and considers how its vernacular aesthetic speaks to the anxieties and desires of Latina/o audiences by celebrating regional cultures while exploring the dynamics of global transition. Despite recent federal prohibitions, narco cinema endures as a popular folk art because it reflects distinctively the experiences of those uprooted by the forces of globalization and critiques those forces in ways mainstream cinema has failed"-_ Provided by publisher.

Includes bibliographical references and index.

1. Drugs in motion pictures. 2. Exploitation films-Mexico-History and criticism. I. Title.

PN1995.9.D78R38 2015

$791.43^{\prime} 6561$-dc23

2014043322

A catalogue record of the book is available from the British Library.

Design by Newgen Knowledge Works (P) Ltd., Chennai, India.

First edition: April 2015

109876654321 
for Joanne Gagnon and Michael Rashotte 
This page intentionally left blank 


\section{Contents}

List of Illustrations ix

Acknowledgments xi

Oye, Lecteur xiii

1 What Is Narco Cinema? 1

2 Hecho de coca: A Sentimental Education 23

3 Two Foul Score of the Brothers Almada 43

4 Narcas y Narcos 103

5 ....and Narco Gays? 135

$\begin{array}{ll}\text { Postscript: From Culiacán to Cannes } & 157\end{array}$

$\begin{array}{ll}\text { Notes } & 165\end{array}$

$\begin{array}{lr}\text { Works Cited } & 179\end{array}$

$\begin{array}{ll}\text { Index } & 191\end{array}$ 
This page intentionally left blank 


\section{Illustrations}

I.1 Unbelievable, unbelievable xiii

1.1 The blood- and coke-smeared mirror 1

2.1 "But our country, too." 23

3.1 One harsh dose of catharsis 43

4.1 La Mariposa Traicionera 103

5.1 ¿i ¿i ?!?! 135

P.1 ¡Que viva narco cinema! 157 
This page intentionally left blank 


\section{Acknowledgments}

Thank you to Ayumi Shimizu for her illustrations and to everyone else involved in research and production. Frederick Luis Aldama, Erica Buchman, Robyn Curtis, raculfright_13, Christian González, Patricia Rojas, and David E. Wilt: your efforts are much appreciated.

For their support, advice, and unreasonable kindness, thanks also to Tomás Diez (R.I.P.), Chris Montgomery, Martha Nandorfy, Bill Nericcio, and Pablo Ramirez.

Above all, thanks to the Gagnon, Rashotte, and Shimizu families, especially my parents (see dedication), Kesatoshi, Mariko, Emi, Vicky, and Pat. Let's add Glenn Brown, Pete Dos Santos, and the rest of the Ajaxians (wherever they roll today).

Ayumi, Ena, and Matt:

(space reserved for something mawkish and copyright) 
This page intentionally left blank 


\section{Oye, Lecteur}

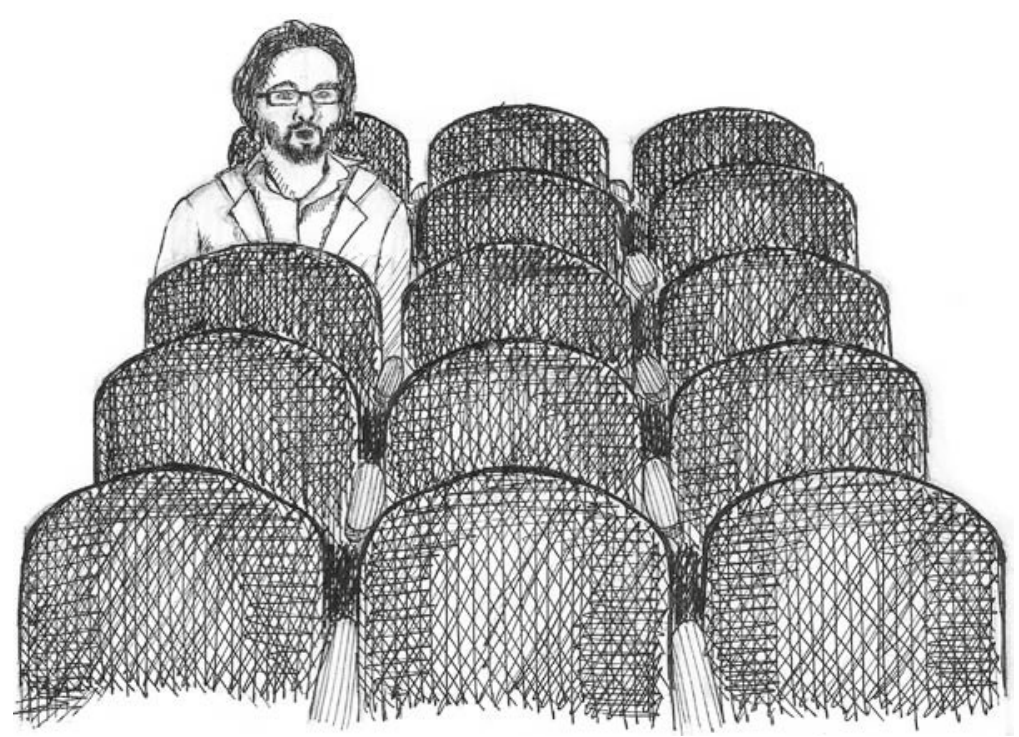

Figure I.1 Unbelievable, unbelievable.

Let's begin in an unlikely place: the Royal Ontario Museum, Toronto, Canada.

In its atrial lobby, to be exact. An elegant soft-lit wonder hall where, on this frosty evening in November 2011, Mexico's premier novelist Carlos Fuentes will be discussing contemporary Mexican culture (this being opening night of the Mayan exhibition, Secrets of their Ancient World). 
At 25 dollars a seat-50 for orchestra pit, which guarantees some catered schmooze time with the distinguished visitor-the hall is surprisingly packed. Row after row of grad students, professors, artists, expats, and all-around cognizant-looking people is thawing raptly next to nimble Crustaceous bones, a bronze Buddha Viarocana, and two faux-Renaissance murals of jousting knights, which frame Fuentes in twinned lance tips as he takes the stage to warm applause and begins to lecture on the past and future of his country.

To call this evening my delight would be underselling it. Major neural pathways in my noggin are blocked off for a semi-annual love parade is more like it. For the better part of my post-Hardy Boys readerly life, Fuentes has been a hero of mine and, because he's 83 years old and a rare visitor to the north country, I'm sure that tonight will be my only chance to collect his signature, maybe swap some oxygen.

Given my state of reverence, it will come as no surprise that I remember little of the lecture today: a word or two about the Revolution; something stern and excursive for the millennial crowd; maybe there was a bit in there on Diego and Frida, or maybe that was just the happiness talkinganyway, it's not important. What matters, for our purpose here, is an incident about to happen at the end of the Q\&A, and this incident I do remember more clearly:

It's time for the final question of the night. A trembling hand is chosen from the audience. The microphone makes an eastern relay through the VIP. The crowd hushes itself, refocuses. Fuentes winces at the thundercrack of a young man clearing his throat into the mike. A young man whose tweed jacket and baroquely ruffled scarf smack noisily of junior faculty. A young man who, with the full attention of one of the world's greatest living authors and his 400-strong crowd, wonders if Fuentes "could perhaps say something about Mexican archetypes as they relate to the drug war today. 
"What is it that persists in the idea of lo mexicano as a kind of dangerous, macho, passionate character; a self-destructive, hyper-violent sensibility; a distinctly Mexican coolness, or what you might call..." This adjectival troop carries on, and is paraphrased here to the best of a dubious memory, ${ }^{1}$ but doubtless you'll gather its implications for a book intro such as this one: this scarf guy is a dickhead. A grade-A bigot. I've summoned him only so that we might recoil cleverly into a thesis on the politics of his bigotry. One doesn't generalize about racial or national "character"-especially in negative terms - in 2011, and if this fellow has undergone a period of self-flagellation and banishment for his smarter circles then maybe there is something like justice among the more lustrous ideals lighting the tenure track.

Now I'll stop you right there. I know what you're thinking, that old conceit: this dapper claude happens to be none other than yours truly, moments before some sort of rhetorical Zen slap from Fuentes corrects my pompousness in a necessarily public way. In that case, I'll be happy to disabuse you: le claude ce n'est pas moi (and Fuentes, incidentally, proves far too nice a guy to take his questioner to task. I don't remember his entire response, something about Al Capone, and Mexico, past or present, holding no monopoly on gangsterism). To find me you'll have to scan the seats in the adjunctfaculty price range. Thirty rows behind the velvet rope (as the scarf flutters), five seats left of the resident hadrosaur-there I am: tweedless, in less pretentious academic fatigues (khaki sport coat, Franzen glasses); alternating looks of disbelief and outrage seemingly slapped across my face by the force of each new modifier-“dangerous," "criminal"; mouth frozen in a Munch scream, maybe doing a little puling so as not-so discreetly to reveal the moral distortion the question continues to cause me as it crackles along. Unbelievable, unbelievable.

More than unbelievable, it's uncanny. Weeks before this gala, I'd defended a graduate dissertation about these 
stereotypes to a word-about how North American representations of a "lawless," "violent" Mexico influence everything from maquila-workers' rights to migration laws to cultures of tourist licentiousness. I am, at this moment, a mental repository for decades of Chicana/o and Latina/o scholarship (to which own my contribution is best considered an endnote to a footnote). And so to hear my fellow Canuck, and clearly a smart and articulate one, present these stereotypes as objective facts-and to Carlos Frickin Fuentes no less-of course you'll understand my angry hands, this Munch and pule business of my face.

The moment at which a leather man-purse, incontinent of several hardcover throwable items, can be heard purring open from the cheap seats is probably a good time to draw curtains on this memory and admit something that would make my younger, more indignant self cringe: our bescarfed inquirer has a point.

It's not a good point. It's not a fair point. What it is is ... you see...four years later, after watching upward of a hundred Mexican narco films-films which on the surface (and it's a wide and thick surface) showcase an orgy of ruthless cholos and brutalizing federales and gold-hearted sicarios and treacherous patronas; films stocked with real-life bazookas and ostrich-skin chaps and blood jewelry and cowboy autosda-fé; films that have done substantial resistance training on my egad and zounds receptors-how could I not concede that this guy, like Octavio Paz (whom surely he got this from, either Paz or Breaking Bad), wasn't onto some history-vetted truth about an abiding violencia in Mexican culture? Not something "essential" perhaps, but a certain something nonetheless that needs be teased out and argued for 200 pages or so, but that still might end up, I'll admit upfront, supporting the stereotypes that had irked me not so long ago.

It's true: watch any narco film and you'll appreciate why the Mexican government and intelligentsia have roundly 
dismissed this b-cinema as vulgar and corruptive and why, in this attempt to celebrate its virtues, I need to acknowledge a fraternal level of hypocrisy from the start. Because as much as I'll resist the temptation, in the pages ahead I already see myself retreating from the hellacious civics of today's humanities departments to the mid-century authority of someone like Paz, someone who pondered essences rather than "cultural constructs," who could say with a straight face things like, "The Mexican views life as combat" or "The Mexican succumbs very easily to sentimental effusions" or "One of the most notable traits of the Mexican's character is his willingness to contemplate horror" or "The Mexican tells lies because he delights in fantasy, or because he is desperate, or because he wants to rise above the sordid facts of his life." 2 There's a kind of gruff self-confirmation in generalizing like this that sounds tyrannical, if not derelict, today. These films have it in volumes. And, if I'm going to be honest, that's partly what makes them so satisfying to this junkie's taste.

So what's my point? Judge not lest ye be judged? No. Is "give Paz a chance" all that I'm saying? That would be a slim chance, though not so slim as I'd have thought in 2011. It's not even that I want to tell you grand definitive things about peoples and cultures in a manly voice, but that because, like any addict's, a defense of my degradation will naturally reflect the terms of my vice, I already see myself slipping into some very harsh octaves in the pages ahead and should be clear about this while you have a chance to back out.

Maybe my point is just this: If you read what follows and take umbrage and come to fantasize about strangling me with an elaborate scarf-and with equally elaborate relish, the strangling; or gashing, clawing, belting; really, just let the demons go to town-please know that I, too, used to be aghast by this sort of thing. And that I could grasp 
xviii Oye, Lecteur

deconstruction and track the hegemonic baggage of the dullest aphorism and never in a decade of scholarly inquest had been so massively entertained. If you can forgive me, I would appreciate it. If you can spare some indulgence, I'll take that, too.

Now let's get a little atrocious. 